\title{
PENGARUH KEPEMIMPINAN, BUDAYA ORGANISASI, KOMPETENSI DAN MOTIVASI TERHADAP KINERJA KARYAWAN DI KSP SUMBER JAYA LAMONGAN
}

\author{
Miftahul Huda \\ Moh. Azus Shony Azar \\ Fakultas Ekonomi Universitas Islam Darul ‘Ulum Lamongan \\ miftahulhuda@unisda.ac.id \\ azus@unisda.ac.id
}

\begin{abstract}
The research is determine the effect of leadership, organizational culture, competence and motivation on employee performance at KSP Sumber Jaya Lamongan. The population in this study are employees at KSP Sumber Jaya Lamongan while the sample population were all employees of cooperatives totaling 30 people, sampling techniques is the saturation sampling because the entire population is used as a sample and also less than 30 people.To obtain the necessary data the authors used data collection techniques such as interviews and questionnaires, techniqueanalysis used in this research is descriptive method. From the discussion concluded that KSP Sumber Jaya Lamongan is a savings and credit cooperatives in which variable competence and work motivation are effected significsnt partially on the performance of employees in KSP Sumber Jaya Lamongan while the leadership and organizational culture are not effected significant partially on performance employeer of at KSP Sumber Jaya Lamongan. So the contribution of variable influence leadership competencies organizational culture and work motivation on employee performance in KSP Sumber Jaya Lamongan amounted to $78.4 \%$, while the remaining $21.6 \%$ is influenced by other variables that not examined.

Keywords : Leadership, Organitational culture, Competence and Work Mottivation.
\end{abstract}

\begin{abstract}
Abstraksi: Penelitian ini bertujuan untuk mengetahui pengaruh kepemimpinan, budaya organisasi, kompetensi dan motivasi terhadap kinerja karyawan di KSP Sumber Jaya Lamongan. Populasi dalam penelitian ini adalah karyawan di KSP Sumber Jaya Lamongan sedangkan sampel populasi adalah seluruh karyawan koperasi yang berjumlah 30 orang, tehnik penentuan sampel adalah dengan sampling jenuh karena seluruh populasi dijadikan sebagai sampel dan juga kurang dari 30 orang. Untuk memperoleh data yang diperlukan penulis menggunakan tehnik pengumpulan data berupa wawancara dan kuisoner, tehnik analisis yang digunakan dalam penelitian ini adalah metode deskriptif. Dari hasil pembahasan disimpulkan KSP Sumber Jaya Lamongan merupakan koperasi simpan pinjam yang mana variable kompetensi dan motivasi kerja berpengaruh secara signifikan secara parsial terhadap kinerja karyawan di KSP Sumber Jaya Lamongan sedangkan kepemimpinan dan budaya organisasi tidak berpengaruh signifikan secara parsial terhadap kinerja karyawan di KSP Sumber Jaya Lamongan. Jadi besarnya kontribusi pengaruh variable kepemimpinan budaya organisasi kompetensi dan motivasi kerja terhadap kinerja karyawan di KSP Sumber Jaya Lamongan adalah sebesar 78,4 \%, sementara sisanya sebesar 21,7 $\%$ dipengaruhi oleh variable lain yang tidak diteliti.
\end{abstract}

Kata Kunci : Kepemimpinan, Budaya Organisasi, Kompetensi dan Motivasi Kerja

\section{PENDAHULUAN \\ Latar Belakang}

Perkembangan perdagangan pada era globalisasi ini tidak dapat dipungkiri tidak luput dari Koperasi Indonesia merupakan alat demokrasi ekonomi dan alat pembangunan masyarakat, yang dilandasi Pancasila dan Undang - Undang Dasar 1945. Kedudukan koperasi di Indonesia dalam perekonomian nasional mendapat tempat yang paling penting sesuai dengan Undang - Undang Dasar 1945 pasal 33 ayat 1 yang menyatakan bahwa perekonomian disusun sebagai usaha bersama berdasar atas asas kekeluargaan. Selanjutnya penjelasan pasal 33 antara lain menyatakan bahwa kemakmuran masyarakatlah yang diutamakan bukan merupakan orang seorang dan bangun perusahaan yang sesuai dengan itu ialah koperasi. Dengan demikian, Undang Undang Dasar 1945 menempatkan koperasi sebagai soko guru perekonomian sekaligus sebagai bagian integral tata perekonomian nasional (Undang - Undang Dasar 945, pasal 33 ayat 1$)$. 
Peningkatan kinerja karyawan di instansi perkoperasian dapat ditempuhdengan beberapa cara, misalnya melalui pemberian kompensasi yang layak,pemberian motivasi, menciptakan lingkungan kerja yang kondusif, budaya organisasi, gaya kepemimpinan, serta pendidikan dan pelatihan. Oleh karena itu, karyawan diharapkan dapat memaksimalkan tanggung jawab mereka setelah dibekali dengan pendidikan dan pelatihan yang berkaitan dengan implementasi pekerjaan mereka. Selain itu, budaya organisasi adalah sebuah keyakinan, sikap dan nilai yang umumnya dimiliki, yang timbul dalam organisasi, dikemukakan dengan lebih sederhana Sedarmayanti (2016:99).Menurut sedarmayanti (2016: 149) kompetensi mencakup berbagai faktor teknis dan non teknis, kepribadian dan tingkah laku, soft skills dan hard skills, kemudian banyak dipengaruhi sebagai aspek yang dinilai banyak perusahaan untuk merekrut karyawan ke dalam organisasi. Sedangkan menurut Mc. Clelland dalam sedarmayanti (2016:150) kompetensi adalah karakteristik mendasar yang dimiliki seseorang yang berpengaruh langsung terhadap atau dapat memprediksikan kinerja yang sangat baik. Dengan kata lain, kompetensi adalah apa yang outstandling performers lakukan lebih sering, pada lebih banyak situasi, dengan hasil yang lebih baik, dari pada apa yang dilakukan penilai kebijakan.Selain kompetensi, faktor lain yang mempengaruhi kinerja karyawan adalah budaya organisasi.

Adapun faktor paling kritikal yang dipandang mempengaruhi kinerja karyawan adalah budaya organisasi.Budaya organisasi dikenal luas sebagai fondasi sistem dan aktivitas manajemen dalam setiap organisasi. Budaya organisasi dipandang sebagai nilai nilai bersama dan norma norma perilaku yang diyakini dan dianut oleh anggota anggota organisasi. Nilai dan norma perilaku tersebut menciptakan pendekatan yang digunakan anggota organisasi dalam melaksanakan pekerjaan dan mengatasi permasalahan yang dihadapi. Menurut Sedarmayanti (2016:99) bahwa Budaya Organisasi adalah sebuah keyakinan, sikap dan nilai yang umumnya dimiliki, yang timbul dalam organisasi, dikemukakan dengan lebih sederhana, budaya adalah cara kita melakukan sesuatu di sini.

Faktor penting yang menentukan kinerja karyawan dan kemampuan organisasi beradaptasi dengan perubahan lingkungan adalah kepemimpinan (leadership). Kepemimpinan menggambarkan hubungan antara pemimpin (leader)dengan yang dipimpin (follower) dan bagaimana seorang pemimpin mengarahkan follower akan menentukan sejauh mana follower mencapai tujuan atau harapan pimpinan. Banyak faktor dapat mempengarui kinerja.

Koperasi simpan pinjam "Sumber Jaya" merupakan suatu lembaga yang bergerak dalam bidang simpan pinjam dan membantu masyarakat dalam mengelola kredit untuk modal usaha. Pembagian kerja yang baik akan terjadi apabila suatu perusahaan atau koperasi menempatkan karyawannya sesuai dengan keahlian, kemampuan dan tingkat pendidikan yang dimilikinya

Berdasarkan uraian diatas, maka penulis tertarik untuk melakukan penelitian dengan judul "pengaruh kepemimpinan, budaya organisasi, kompetensi dan motivasi terhadap kinerja karyawan di KSP Sumber Jaya Lamongan".

\section{RUMUSAN MASALAH}

Rumusan Masalah dalam penelitian ini adalah

1. Apakah kepemimpinan berpengaruh terhadap kinerja karyawan pada KSP "Sumber Jaya"Lamongan?

2. Apakah budaya organisasi berpengaruh terhadap kinerja karyawan pada KSP "Sumber Jaya"Lamongan?

3. Apakah kompetensi berpengaruh terhadap kinerja karyawan pada KSP "Sumber Jaya"Lamongan?

4. Apakah motivasi kerja berpengaruh terhadap kinerja karyawan pada KSP "Sumber Jaya"Lamongan.

5. Apakah kepemimpinan,budaya organisasi, kompeensi dan motivasi berpengaruh secara bersama-sama terhadap kinerja karyawan pada KSP "Sumber Jaya"Lamongan?

\section{TINJAUAN PUSTAKA}

\section{Landasan Teori}

\section{Kinerja Karyawan}

Menurut Abdullah (2014:3) Kinerja itu adalah terjemahan dari performance yang berarti hasil kerja atau prestasi kerja. Dan dalam pengertian yang simpel kinerja adalah hasil dari pekerjaan organisasi, yang dikerjakan oleh karyawan dengan sebaik- baiknya sesuai dengan petunjuk (manual), arahan yang diberikan oleh pimpinan (manajer), kompetensi dan kemampuan karyawan mengembangkan nalarnya dalam bekerja. 
Dengan demikian dapat disimpulkan bahwa kinerja adalah prestasi kerja yang merupakan hasil dari implementasi renvna kerja yang dibuat oleh suatu instansi yang dilaksanakan oleh pemimpin dan karyawan (SDM) yang bekerja diinstansi itu baik pemerintah maupun perusahaan (bisnis) untuk mencapai tujuan orgaanisasi. Sedangkan karyawan itu adalah sumber daya manusia atau penduduk yang di suatu instansi baik pemerintahan maupun swasta (bisnis). Proses dalam pemahaman kebutuhan dan keinginan konsumen inilah yang menjadi konsep pemasaran. Seseorang yang bekerja dibidang pemasaran disebut pemasar. Pemasaran ini sebaiknya terampil dalam merangsang permintaan akan produk-produk perusahaan agar kegiatan pemasaran dapat tercapai sesuai dengan kebutuhan dan keinginan manusia terutama pihak konsumen yang dituju.

\section{Gaya Kepemimpinan}

Stogdill dalam Sedarmayanti (2016:273) mengemukakan bahwa kepemimpinan adalah suatu proses mempengaruhi aktivitas kelompok dalam upaya perumusan dan pencapaian tujuan, sedangkan Siagian dalam Sedarmayanti (2016: 273) sebelumnya menyatakan bahwa kepemimpinan merupakan inti manajemen karena kepemimpinan adalah motor penggerak bagi sumber daya dan sumber daya lainnya.

Siagian dalam sedarmayanti
$(2016: 273) \quad$ mengutarakan tentang berbagai teori kepemimpinan yang dibagi menjadi tiga bagian:

1 Teori Genetik: kepemimpinan dibawa sejak manusia lahir ke dunia.

2 Teori Sosial: seseorang pemimpin akan dapat menjadi pemimpin karena diciptakan oleh masyarakat.

3 Teori Ekologis: calon pemimpin, sedikit banyak telah membawa bakat sejak lahir, tetapi bakat saja belum cukup dijadikan modal memimpin. Karena itu bakat harus dilengkapi dengan pendidikan dan pengalaman hidup, sehingga ia berhasil menjadi pemimpin. Diantara tiga teori pemimpin ini, teori yang dianggapa paling mendekati kebenaran dan mempunyai pengikut yang banyak dalam situasi sekarang adalah teori ekologis.

\section{Budaya Organisasi}

Sedarmayanti (2016:99) bahwa Budaya Organisasi adalah sebuah keyakinan, sikap dan nilai yang umumnya dimiliki, yang timbul dalam organisasi, dikemukakan dengan lebih sederhana. Budaya adalah cara kita melakukan sesuatu disini. Pola nilai, norma, keyakinan, sikap dan asumsi ini mungkin diungkapkan, tetapi akan membentuk cara orang berperilaku dan melakukan sesuatu. Budaya Organisasi merupakan aspek subjektif dari apa yang terjadi di dalam organisasi.

1. Kegunaan Budaya Organisasi

Sedarmayanti (2016:100) Budaya menampilkan "Perekat Sosial" dan menghasilkan "Perasaan Kekamian" sehingga meniadakan proses diferensiasi yang merupakan bagian dari kehidupan organisasi yang tidak dapat dihindari. Dimana menjadi dasar untuk komunikasi dan pemahaman bersama. Jika fungsini tidak direalisasikan dalam suatu cara yang layak, budaya mungkin secara signifikan mengurangi efisiensi organisasi.

2. Menganalisis Budaya Organisasi

Harison dalam Sedarmayanti (2016:100) katagori ideologi organisasi terdiri dari:

1. Berorientasi Kekuatan: kompetitif, responsif terhadap kepribadian dari pada terhadaap keahlian.

2. Berorientasi Orang: berkaitan dengan konsensus, kontrol manajemen yang ditinggalkan.

3. Berorientasi Tugas: menuaskan perhatian pada kompetensi dinamika.

4. Berorientasi Peran: memusatkan perhatian pada legalitas, legitimadsi, dan birokrasi

Sedangkan Handy dalam Sedarmayanti (2016:100) menyatakan bahwa tipe budaya adalah:

1. Budaya Kekuatan: merupakan sumber kekuatan inti yang menjalankan kontrol.

2. Budaya Peran: pekerjaan dikontrol oleh prosedur dan peraturan serta peran atau deskripsi jabatan.

3. Budaya Tugas: tujuannya membawa bersama orang yang tepat dan membiarkan mereka melakukan tugas.

4. Budaya Orang: individu adalah titik utama.

\section{Kompetensi}


Sedarmayanti,(2014:125)Kompetensi mencamgkup berbagai faktor teknis dan non teknis, kepribadian dan tingkah laku, soft skills, dan hard skill, kemudian banyak digunakan sebagai aspek yang dinilai nbanyak perusahaan untuk merekrut karyawan ke dalam organisasi, sedangkan Andersen, Martoyo (2003) dalam Sedarmayanti (2016:20) menyatakan bahwa Kompetensi adalah sebagai karakteristik dasar yang membedakan seseorang yang perform dan tidak perform. Ini berarti inti utama dari sistem atau model kompetensi sebenarnya adalah alat pembentuk untuk memprediksi keberhasilan kerja seseoreang pada suatu posisi/ jabatan tertentu.

Hay Mc. Ber (1993) dalam Sedarmayanti (2014:127) Berdasarkan penelitian dengan sampel 20 negara, maka jenis pekerjaan dan industri ditentukan 18 kompetensi bersifak "genetik" yang umum ditemui pada berbagai pekerjaan dan industri, yaitu:

1) Orientasi pencapaian

2) Berpikir analitis

3) Berpikir konseptual

4) Orientasi layanan pelanggan

5) Mengembangkan lainnya

6) Pengintruksian

7) Fleksibilitas

8) Dampak dan pengaruh

9) Pencarian informasi

10) Inisiatrif

11) Integrasi

12) Pengembangan antar pribadi

13) Kesadaran Organisasional

14) Komitmen organisasi

15) Menjalin hubungan

16) Rasa percaya diri

17) Kepemimpinan dalam kelompok

18) Kerja sama dan kelompok kerja

\section{Motifasi Kerja}

George R Terry dalam Sedarmayanti (2016:257) Motivasi adalah keinginan yang terdapat pada seseorang individu yang merangsangnya melakukan tindakan.sedangkan Siagian dalam Sedarmayanti (2016: 257) menyatakan bahwa motivasi adalah keseluruhan proses pemberian motivasi kerja kepada bawahan sedemikian rupa sehingga mereka mau bekerja dengan ikhlas demi tercapainya tujuan organisasi dengaan efisien dan ekonomis.
Sedarmayanti

(2016:257)

menyatakan, Motivasi merupakan kesedihan mengeluarkan tingkaat upaya tinggi ke arah tujuan organisasi yang dikondisikan oleh kemampuan upaya itu untuk memenuhi kebutuhan individual. Unsur upaya merupakan ukuran intesitas. Bila seseorang termotivasi, ia akan mencoba kuat. Tujuan organisasi adalah upaya yang seharusnya. Kebutuhan suatu keadaan internal yang menyebabkan hasil tertentu tampak menarik.

Pendekatan Motivasi adalah bahwa pemimpin menciptakan iklim yang dapat membuat anggota merasa termotivaasi. Anggota hendaknya mendapat inspirasi sehingga merasakan adanya harapan dan ketersediaan dalam organisasi dimana ia bekerja. Kepemimpinan dan motivasi merupakan dua hal yang tidak dapat dipisahkan. Dalam kebanyakan hal, motivasi seseorang individu akan timbul karena pengaruh pemimpin yang efektif. Jadi efektifitas kepemimpinan akan tampak bagaimana dapat memotivasi anggotanya efektif.

\section{Penelitian Terdahulu}

Beberapa penelitian yang terkait dengan variabel-variabel yang berpengaruh terhadap kepuasan konsumen adalah sebagai berikut:

Bahua, Angsari, Saleh dan Purnaba (2010) dengan judul "Analisis Faktor- Faktor yang Mempengaruhi Kinerja Penyuluh Pertanian dan Dampaknya pada Perilaku Petani Jagung di Provinsi Gorontalo", dengan menggunakan alat analisis Regresi Linier Berganda yang mana hasil penelitiannya adlah variabel karakteristik penyuluh, kompetesi penyuluh, motivasi penyuluh, dan kemandirian penyuluh mempunyai pengaruh secara signifikan terhadap variabel kinerja. Hubungan dengan penelitian ini adalah samasama meneliti tentang faktor- faktor yang berpengaruh terhadap kinerja pegawai.

Brahmasari dan Suprayetno (2008) dengan judul "Pengaruh motivasi kerja, kepemimpinan, dan budaya organisasi terhadap kepuasan kerja serta dampaknya pada kinerja perusahaan", dengan menggunakan alat analisis Regresi Linier Berganda yang mana hasil penelitiannya adlah variabel motivasi kerja tidak berpengaruh secara signifikan terhadap kinerja perusahaan sedangkan variabel kepemimpinan dan budaya organisasi berpengaruh secara signifikan terhadap kinerja perusahaan. Hubungan 
dengan penelitian ini adalah sama- sama meneliti tentang variabel kepemimpinan dan budaya organisasi.

Wahyuni, Idris, dan Noor (2013) dengan judul "Analisis Faktor- Faktor yang Mempengaruhi Kinerja Pegawai Koperasi Rama Jaya di kota makasar", dengan menggunakan alat analisis Regresi Linier Berganda yang mana hasil penelitiannya adlah faktor- faktor yang mempengaruhi kinerja pegawai sangat berpengaruh secara signifikan terhadap peningkatan kinerja karyawannya. Hubungan dengan penelitian ini adalah samasama meneliti tentang faktor- faktor yang mempengaruhi peningkatan kinerja pegawai.

\section{Kerangka Konseptual}

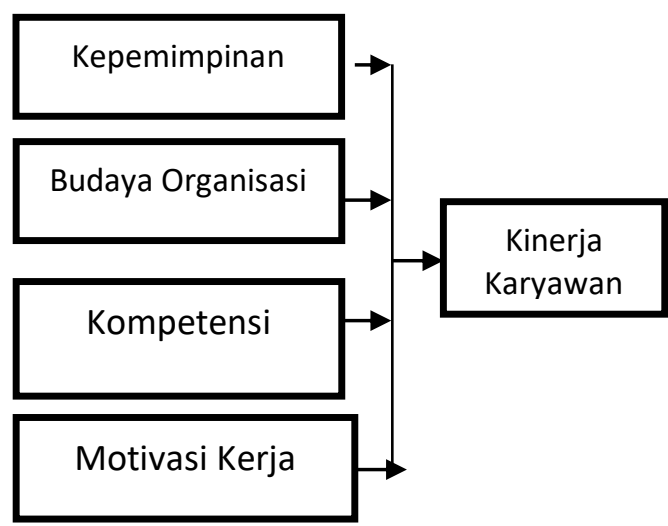

\section{Hipotesis}

- H1: Diduga Kepemimpinan berpengaruh secara positif terhadap peningkatan kinerja karyawan pada KSP "Sumber Jaya" Lamongan

- H2: Diduga Budaya Organisasi berpengaruh secara positif terhadap peningkatan kinerja karyawan pada KSP "Sumber Jaya" Lamongan

- H3: Diduga Kompetensi berpengaruh secara positif terhadap peningkatan kinerja karyawan pada KSP "Sumber Jaya" Lamongan

- H4: Diduga Motivasi Kerja berpengaruh secara positif terhadap peningkatan kinerja karyawan pada KSP "Sumber Jaya" Lamongan

\section{METODE PENELITIAN}

\section{Pendekatan Penelitian}

Jenis penelitian ini adalah penelitian dengan menggunakan metode survey yaitu suatu metode yang digunakan untuk mendapatkan data dari tempat tertentu yang alamiah (bukan buatan), tetapi peneliti melakukan perlakuan dalam pengumpulan data, misalnya dengan mengedarkan kuesioner, test, wawancara terstruktur dan sebagainya atau perlakuan tidak seperti dalam eksperimen ( Sugiyono, 2010: 11).

\section{Populasi dan Teknik Pengambilan Sampel}

\section{Populasi}

Populasi dalam penelitian ini menurut jenisnya merupakan populasi yang terbatas dan menurut sifatnya merupakan populasi yang homogen. Populasi dalam penelitian ini adalah seluruh karyawan KSP "Sumber Jaya" Lamongan sejumlah 30 orang pegawai.

\section{Sampel dan Teknik Pengambilan Sampel}

Sampel dari penelitian ini adalah seluruh karyawan yang ada di KSP "Sumber Jaya" Lamongan yang berjumlah 30 karyawan. Jenis sampel yang digunakan ini termasuk sampling jenuh yaitu teknik penentuan sampel bila semua anggota populaasi digunakan sebagai sampel. Hal ini sering dilakukan bila jumlah populasi relatif kecil, kurang dari 30 orang. Islitah lain sampel jenuh adalah sensus, dimana semua anggota populasi dijadikan sampel (Sugiyono, 2010:122)

Teknik pengambilan sampel dalam penelitian ini dilakukan dengan teknik Sampling jenuh. Sedangkan Sampling jenuh merupakan teknik penentuan sampel bila semua anggota populasi digunakan sebagai sampel. Hal ini sering dilakukan bila jumlah populasi relatif kecil, kurang dari 30 orang atau penelitian yang ingin membuat generalisasi dengan kesalahan yang sangat kecil. Istilah lain sampel jenuh adalah sensus, dimana semuan anggota populasi dijadikan sampel. Pelaksanaan Accidental Sampling dalam penelitian ini diberikan kepada karyawan yang bekerja di KSP "Sumber Jaya" Lamongan.

\section{Metode Pengumpulan Data}

Metode pengumpulan data yang digunakan adalah:

1. wawancara

2. angket atau kuesioner.

Wawancara adalah teknik pengumpulan data yang mendasarkan diri pada laporan tentang diri sendiri untuk self report atau 
setidak- tidaknya pada pengetahuan dan atau keyakinan pribadi. Wawancara di dalam penelitian ini dilakukan pada karyawan KSP "Sumber Jaya" Lamongan yang berjumlah 30 orang pegawai.

Kuesioner atau angket adalah teknik pengumpulan data yang dilakukan dengan cara memberi seperangkat pertanyaan atau pertanyaan tertulis responden untuk dijawab.Kuesioner yang dimaksud dalam penelitian ini adalah jawaban dari karyawan KSP "Sumber Jaya" Lamongan.

\section{Definisi Operasional dan Pengukuran Variabel}

\section{Kepemimpinan (X1)}

Kepemimpinan adalah cara yang digunakan oleh seorang pemimpin koperasi untuk mempengaruhi di dalam mengatur dan mengkoordinasikan karyawan dalam rangka mencapai tujuan koperasi yang efisien.

Indikator kepemimpinan diukur dari:

1. Kemampuan untuk memberitahu anggota apa yang harus mereka kerjakan

2. Pemimpin mampu memberikan ide- ide kepada anggota KSP "Sumber Jaya" lamongan.

3. Kemampuan berpartisipasi dengan anggota KSP "Sumber Jaya" lamongan.

\section{Budaya Organisasi (X2)}

Budaya Organisasi adalah sebuah keyakinan, sikap dan nilai yang umumnya dimiliki, yang timbul dari KSP "Sumber Jaya" lamongan.

Indikator budaya organisasi diukur dari:

1. Tuntutan kerja untuk karyawan KSP "Sumber Jaya" lamongan.

2. Toleransi untuk karyawan KSP "Sumber Jaya" lamongan dalam berbagai kesalahan sebagai peluang untuk belajar.

3. Dukungan kerja sama lingkungan kerja fisik karyawan KSP "Sumber Jaya" lamongan.

\section{Kompetensi (X3)}

Kompetensi adalah kemampuan untuk melakukan suatu pekerjaan sesuai dengan bidangnya sediri pada KSP "Sumber Jaya" lamongan.

Indikator kompetensi diukur dari:

1. Pengetahuan ilmu yang dimiliki karyawan KSP "Sumber Jaya" lamongan.

2. Keterampilan yang digunkan karyawan
KSP "Sumber Jaya" lamongan untuk melakukan pekerjaan.

3. Sikap kerja yang cekatan dalam pekerjaan.

\section{Motivasi Kerja (X4)}

Motivasi Kerja adalah proses dengan mana perilaku dibangkitkan, diarahkan,dan dipertahankan selama berjalannya waktu dalam KSP "Sumber Jaya" lamongan

Indikator motivasi kerja diukur dari:

1. Kebutuhan berprestasi karyawan KSP "Sumber Jaya" lamongan.

2. Kebutuhan fisik karyawan KSP "Sumber Jaya" lamongan.

3. Kebutuhan rasa aman karyawan KSP "Sumber Jaya" lamongan.

\section{Kinerja Karyawan (Y)}

Adalah variabel yang diduga sebagai akibat atau dipengaruhi oleh variabel yang mendahuluinya.variabel terikat yang dimaksud disini adalah kinerja karyawan.Kinerja adalah hasil kerja yang secara kualitas dan kuantitas dapat dicapai oleh seorang karyawan KSP "Sumber Jaya" lamongan dalam melaksanakan tugasnya sesuai tanggung jawab yang diberikan kepadanya.

Indikator kinerja karyawan dapat diukur dari:

1. Kemampuan karyawan dalam meningkatkan efisiensi penggunaan seluruh waktu yang dimiliki.

2. Kemampuan karyawan dalam beradaptasi terhadap perubahan.

3. Kemampuan karyawan dalam mencapai target yang telah ditetapkan.

\section{Metode Analisis Data \\ Uji Validitas}

Uji Validitas digunakan untuk mengukur sah atau valid tidaknya suatu kuesioner (Ghozali,2006:177). Suatu kuesioner dikatakan valid jika pertanyaan pada kuesionet mampu untuk mengungkapkan sesuatu yang akan diukur oleh kuesionet tersebut. Uji validitas dapat dilakukan dengan membandingkan nilai $r$ hitung dengan $r$ tabel untuk degree of freedom $(\mathrm{df})=\mathrm{n}-4$, dalam hal ini $\mathrm{n}$ adalah jumlah sampel. Suatu indikator dikatan valid, apabila $\mathrm{df}=\mathrm{n}-4=30$ $-4=26$ dan $\alpha=0,05$, maka $r$ tabel $=0,198$ dengan ketentuan (Ghozali, 2015):

Hasil $r$ hitung $>$ tabel $(0,198)=$ valid

Hasil $r$ hitung $<$ tabel $(0,198)=$ tidak valid

Hasil validitas dapat dilihat pada ouput Alpha Cronbach pada Correcred Item - Total Correlation. Bandingkan nilai Correlated Item 
- Total Correlation dengan hasil perhitungan $r$ tabel. Jika $r$ hitung $>\mathrm{r}$ tabel dan nilai positif, maka butir pernyataan atau indikator tersebut dinyatakan valid (Ghozali, 2006: 177).

\section{Realibilitas}

Realibilitas adalah alat untuk mengukur suatu kuesioner yang merupakan indikator dari variabel atau konstruk (Ghozali,2005: 183).Suatu kuesioner dikatakan reliabel atau handal jika jawaban seseorang terhadap pernyataan adalah konsisten atau stabil dari waktu ke waktu. Jawaban respondent terhadap pertanyaan ini dikatakan reliabel jika masingmasing pertanyaan dijawab secara konsisten atau jawaban tidak boleh acak oleh karena masing- masing pertanyaan hendak mengukur hal yang sama. Jika jawaban terdapat indikator ini acak, maka dapat dikatakan bahwa tidak reliabel (Ghozali, 2005: 183).

Alat untuk mengukur reliabilitas adalah Alpha Cronbach, suatu variabel dikatakan reliabel, apabila (Ghozali, 2005):

Hasil Alpha Conbach >0,60 = reliabel

Hasil Alpha Conbach $<0,60=$ tidak reliabl

\section{Analisi Regresi Linier Berganda}

Analisi Regresi Linier Berganda dugunakan untuk mengetahui pengaruh variabel bebas terhadap variabel tidak bebas (terikat) atas perubahan dari setiap peningkatan atau penurunan variabel bebas yang akan mempengaruhi variabel terikat (Sugiyono, 2008: 277)

Rumus (Sugiyono, 2008: 277):

$$
\mathrm{Y}=\mathrm{a}+\mathrm{b} 1 \mathrm{X} 1+\mathrm{b} 2 \mathrm{X} 2+\mathrm{b} 3 \mathrm{X} 3+\mathrm{b} 4 \mathrm{X} 4+\mathrm{e}
$$

\section{Uji Asumsi Klasis}

\section{a. Uji Normalitas}

Uji Normalitas bertujuan untuk menguji apakah data yang akan digunakan dalam model regresi berdistribusi normal atau tidak (Ghozali, 2006: 229 ). Untuk menguji suatu data berdistribusi normal atau tidak, dapat diketahui dengan menggunakan grafik normal plot. Pada grafik normal plot, dengan asumsi:

1. Apabila data menyebar disekitar garis diagonal dan mengikuti arah garis diagonal atau grafik histogramnya menunjukkan pola distribusi normal, maka model regresi memenuhi asumsi normalitas.

2. Apabila data menyebar jauh dari diagonal dan/ atau tidak mengikuti arah garis diagonal atau grafik histogram tidak menunjukkan pola distribusi normal, maka model regresi tidak memenuhi uji asumsi normalitas.

b. Uji Heteroskedastisitas
Uji Heteroskedastisitas bertujuan menguji apakah dalam model regresi terjadi ketidaksamaan variance dari residual satu pengamatan ke pengamatan yang lain. Jika variance dari residual satu pengamatan ke pengamatan lain tetap, maka disebut homokedasrtisitas dan jika berbeda disebut heteroskedastisitas. Model regresi yang baik adalah heteroskedastisitas atau tidak terjadi heteroskedastisitas (Ghozali,2006:301). Deteksi ada tidaknya problem heteroskedastisitas adalah dengan media grafik.

c. Uji Multikolinearitas

Uji Multikolinearitas bertujuan untuk menguji apakah model regresi ditemukan adanya korelasi antar variabel bebas. Model regresi yang baik seharusnya tidak terjadi korelasi diantara variabel bebas. Jika variabel bebas saling berkorelasi, maka variabelvariabel ini tidak ortogonal. Variabel ortogonal adalah variabel bebas yang nilai korelasi antar sesama variabel bebas sama dengan nol (0). Untuk mendeteksi ada atau tidaknya multikolinearitas di dalam model regresi adalah sebagai berikut (Ghozali, 2006: 303):

Mempunyai angka Tolerance diatas (>) 0,1

Mempunyai nilai VIF di bawah $(<) 10$

Metode analisis yang digunakan untuk penelitian ini adalah metode analisis regresi linier berganda.Data yang diperoleh dimasukkan ke dalam program pengolahan data yaitu program SPSS (Statistical for Product and Service Solution) versi 18. Kemudian output dari hasil penyebaran kuesioner akan memberi informasi berapa besar tingkat signifikan, valid dan reliabelnya suatu data yang dihasilkan antara beberapa faktor yang mempengaruhi kinerja karyawan.

Adapun teknik landasan utama yang digunakan oleh penulis adalah teknik analisis regresi linier berganda dimana teknik tersebut menjelaskan hubungan antara variabel terikat dengan variabel bebas.

Persamaan regresi linier berganda tersebut adalah :

$$
\mathrm{Y}=\mathrm{a}+\mathrm{b}_{1} \mathrm{X}_{1}+\mathrm{b}_{2} \mathrm{X}_{2}+\mathrm{b}_{3} \mathrm{X}_{3}+\mathrm{b}_{4} \mathrm{X}_{4}+\mathrm{e}
$$

d. Koefisien Determinasi (RSquare)

Koefisien determinasi $\left(R^{2}\right)$ pada intinya mengukur seberapa jauh kemampuan model (kepemimpinan, budaya organisasi, kompetensi dan motivasi kerja) dalam menerangkan variasi variabel dependen/ tidak bebas (kinerja karyawan).

e. Pengujian Hipotesis 
Uji t

Uji t digunakan untuk menguji apakah variabel independen berpengaruh terhadap variabel dependen secara individu. Pengambilan keputusan ini dilakukan berdasarkan perbandingan nilai signifikan dari nilai hitung masing- masing koefisien regresi dengan tingkat signifikasi yang telah ditetapkan yaitu sebesar $5 \%(\alpha=0,05)$.

\section{HASIL PENELITIAN}

\section{Deskripsi Obyek Penelitian}

Pada awalnya koperasi ini berdiri dari pemikiran salah satu warga Desa Sumberjo yaitu bapak Agus Triyono yang memperhatikan dengan seksama para pedagang kaki lima yang setiap hari selalu menjajakan barang dagangannya ke setiap rumah, seperti pedagang tahu campur, nasi goreng, tahu petis, bakso, mie ayam, pedagang sayur dan ikan, warung pecel dan lain-lain.

Pada awal tahun 2007, Bapak Agus Triyono terbesit pemikiran untuk memberikan kredit modal kerja kepada para pedagang tersebut secara legal. Pada saat itu, Bapak Agus mengajak Bapak Sukri dan Bapak Taswandi untuk bergabung.Hal ini menjadi peluang untuk menselaraskan atau memadukan dalam suatu wadah yaitu koperasi. Koperasi itu dinamakan "SUMBER JAYA".

Koperasi Sumber Jaya diresmikan pada tanggal 09 Agustus 2007 dengan Badan Hukum No. 518/ BH/ XVI.10/ 09/ 413. 110/ 2007, dengan jumlah anggota 30 orang, dan simpanan pokok Rp. $1.000 .000,-$ dari masing-masing anggota. Sehingga sebagai modal awal, simpanan pokok yang terkumpul sebesar Rp.30.000.000,-.

Koperasi Sumber Jaya mempunyai kantor pusat di Desa Sumberjo- Dampit Lamongan. Selain itu memiliki kantor cabang di pasar Lamong Raya jalan Panglima Sudirman stand K. 15 Lamongan, dan unit perdagangan di jalan Kusuma Bangsa kompleks pasar burung Lamongan.

Koperasi Sumber Jaya mempunyai tujuan meningkatkan kesejahteraan anggota pada khususnya dan masyarakat pada umumnya.Selain itu, Koperasi Sumber Jaya didirikan dengan Visi dan Misi. Visi Koperasi Sumber Jaya adalah terwujudnya koperasi sebagai pelaku ekonomi masyarakat yang sehat, tangguh dan mandiri, menjadi keuangan lembaga terbaik, dikelola oleh SDM (Sumber Daya Manusia) yang profesional dan peduli sesama serta berkembang bersama setiap individu yang terlibat didalamnya. Sedangkan Misi Koperasi Sumber Jaya antara lain :

a. Meningkatkan kemampuan ekonomi anggota dan masyarakat

b. Menerapkan manajemen yang profesional

c. Meningkatkan peran koperasi dalam tata ekonomi masyarakat

d. Meningkatkan pelaksanaan sistem ekonomi kerakyatan

e. Memberikan jasa keuangan yang beragam dan bermutu

f. Meningkatkan semangat kinerja layanan kepada anggota, dan masyarakat sebagai pelanggan.

\section{Penilaian Responden}

\begin{tabular}{|l|l|l|l|}
\hline $\begin{array}{l}\text { N } \\
\text { o }\end{array}$ & Simbol & Variabel & Total \\
\hline 1 & X1 & Kepemimpinan & 344 \\
\hline 2 & X2 & $\begin{array}{l}\text { Budaya } \\
\text { Organisasi }\end{array}$ & 377 \\
\hline 3 & X3 & Kompetensi & 344 \\
\hline 4 & X4 & Motivasi Kerja & 338 \\
\hline 5 & Y & Kinerja Karyawan & 348 \\
\hline
\end{tabular}

\section{Keterangan:}

1. Bahwa rata-rata pada kepemimpinan adalah setuju. Artinya responden setuju kepemimpinan menjadi salah satu faktor penting yang mempengaruhi kinerja karyawan di Koperasi simpan pinjam Sumber Jaya Lamongan.

2. Bahwa rata-rata pada budaya organisasi adalah setuju. Artinya responden setuju budaya organisasi menjadi salah satu faktor penting yang mempengaruhi kinerja karyawan di Koperasi simpan pinjam Sumber Jaya Lamongan.

3. Dapat disimpulkan bahwa rata-rata pada kompetensi adalah setuju. Artinya responden setuju kompetensi menjadi salah satu faktor penting yang mempengaruhi kinerja karyawan di Koperasi simpan pinjam Sumber Jaya Lamongan.

4. Dapat disimpulkan bahwa rata-rata pada motivasi kerja adalah setuju. Artinya responden setuju motivasi kerja menjadi salah satu faktor penting yang mempengaruhi kinerja karyawan di Koperasi simpan pinjam Sumber Jaya Lamongan.

5. Dahwa rata-rata pada kinerja karyawan adalah setuju. Artinya responden setuju kinerja karyawan menjadi hasil akhir yang diperoleh Koperasi simpan pinjam 
Sumber Jaya Lamongan.

\section{Pengujian Instrumen} Uji Validitas

Tabel 4.7

Hasil Uji Validitas Butir Kuisioner KMO and Bartlett's Test

Kaiser-Meyer-Olkin Measure of Sampling Adequacy. Bartlett's Test of Sphericity

\begin{tabular}{l|r} 
Appro & 10 \\
X. Chi- & 5.1 \\
Square & 93 \\
Df & 10
\end{tabular}

Sumber: Data Primer diolah (2020)

Menurut Arikunto (dalam Duwi Priyatno, 2009:17) bahwa apabila $r_{\text {hitung }}>r_{\text {tabel }}$, maka dapat dikatakan bahwa suatu instrumen adalah valid. Dari hasil pengujian validitas pada tabel 4.7 dapat dilihat bahwa keseluruhan item variabel penelitian mempunyai $r$ hitung $>r$ tabel pada tingkat kesalahan $1 \%(\alpha=0,01)$ dan $n$ $=30$ diperoleh $\mathrm{r}$ table $=0,642$ maka dapat diketahui $\mathrm{r}$ hasil tiap-tiap item $>0,642$ sehingga dapat dikatakan bahwa keseluruhan item variabel penelitian adalah valid untuk digunakan sebagai instrumen dalam penelitian atau pertanyaan-pertanyaan yang diajukan dapat digunakan untuk mengukur variabel yang diteliti.

\section{Uji Reliabilitas}

\section{Hasil Pengujian Reliabilitas Reliability Statistics}

\begin{tabular}{|r|c|r|}
\hline & $\begin{array}{c}\text { Cronbach's } \\
\text { Alpha Based } \\
\text { on } \\
\text { Cronbach's } \\
\text { Alpha }\end{array}$ & \\
\hline .837 & $\begin{array}{c}\text { Standardized } \\
\text { Items }\end{array}$ & N of Items \\
\hline & .824 & 5 \\
\hline
\end{tabular}

Sumber: Data Primer diolah (2020)

Dari hasil tabel di atas dapat dikatakan nilai cronbach alpha, dimana variable kepemimpinan $\left(\mathrm{X}_{1}\right)$, budaya organisasi $\left(\mathrm{X}_{2}\right)$, kompetensi $\left(\mathrm{X}_{3}\right)$, motivasi kerja $\left(\mathrm{X}_{4}\right)$, dan kinerja karyawan (Y) menunjukkan nilai Cronbach's Alpha $(\alpha)>$ 0,6 yang berarti semua variabel reliabel. Hal ini berarti bahwa item pertanyaan yang digunakan akan mampu memperoleh data yang konsisten dalam arti jika pertanyaan tersebut diajukan lagi akan diperoleh jawaban yang Relatif sama

\section{Pengujian Analisis Data}

1. Regresi Berganda

Tabel 4.9

Regresi Linier Berganda

Coefficients

\begin{tabular}{|r|r|r|r|r|}
\hline \multicolumn{2}{|c|}{$\begin{array}{c}\text { Unstandardized } \\
\text { Coefficients }\end{array}$} & $\begin{array}{c}\text { Standardiz } \\
\text { ed } \\
\text { Coefficien } \\
\text { ts }\end{array}$ & & \\
\cline { 1 - 2 } B & Std. Error & \multicolumn{1}{c|}{ Beta } & \multicolumn{1}{c|}{$\mathrm{t}$} & \multicolumn{1}{c|}{ Sig. } \\
\hline 2.616 & 1.064 & & 2.458 & .021 \\
-.032 & .087 & -.039 & -.372 & .713 \\
-.187 & .082 & -.166 & -2.263 & .033 \\
.625 & .092 & .668 & 6.780 & .000 \\
.374 & .088 & .406 & 4.249 & .000 \\
\hline
\end{tabular}

a. Dependent Variable: kinerja karyawan

Sumber: Data Primer diolah (2020)

\section{Persamaan Regresi Berganda}

$\mathbf{Y}=\mathbf{a}+\mathrm{bl} \mathbf{X} 1+\mathrm{b} 2 \mathrm{X} 2+\mathrm{b3} \mathrm{X3}+\mathrm{b} 4 \mathrm{X} 4+\mathrm{e}$ $\mathrm{Y}=2,616-0,032 \mathrm{X} 1-0,187 \mathrm{X} 2+0,625 \mathrm{X} 3+$ $0,374 X 4$

1. Konstanta $\mathrm{a}=2,616$, artinya apabila variabel kepemimpinan, budaya organisasi, kompetensi, dan motivasi kerjasama dengan nol atau tidak berubah, maka nilaiY atau kinerja karyawan sebesar 2,616.

2. Nilai koefisien kepemimpinan untuk variabel $\mathrm{X}_{1}$ sebesar -0,032. Hal inimengandung arti bahwa setiap penurunanvariabel kepemimpinan satu satuan, maka kinerja karyawanakan turun sebesar-0,032 dengan asumsi bahwa variabel bebas yang lain dari model regresi adalah tetap.

3. Nilai koefisien budaya organisasi untuk variabel $\mathrm{X}_{2}$ sebesar $-0,187$. Hal inimengandung arti bahwa setiap penurunanvariabel budaya organisasi satu satuan, maka kinerja karyawan akan turun sebesar -0,187dengan asumsi bahwa variabel bebas yang lain dari model regresi adalah tetap.

4. Nilai koefisien kompetensi untuk variabel $\mathrm{X}_{3}$ sebesar 0,625. Hal ini mengandungarti bahwa setiap kenaikan kompetensi satu satuan, maka kinerja karyawanakan naik sebesar 0,625 dengan asumsi bahwa variabel bebas yang lain darimodel regresi adalah tetap.

5. Nilai koefisien motivasi kerja untuk variabel $\mathrm{X}_{4}$ sebesar 0,374. Hal ini mengandung artibahwa setiap kenaikan motivasi kerja satu satuan, maka kinerja karyawan akannaik sebesar 0,374 dengan 
asumsi bahwa variabel bebas yang lain dari modelregresi adalah tetap.

\section{Asumsi Klasik}

\section{UJi Normalitas}

\section{Pengujian Normalitas}

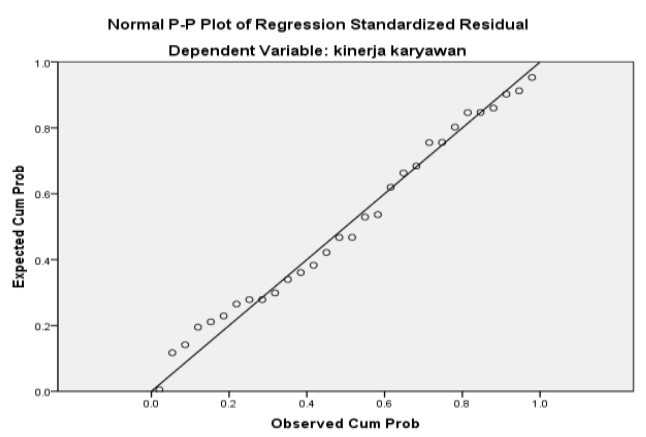

Gambar 4.1

Sumber: Data Primer diolah (2020)

Berdasarkan hasil analisis data dengan menggunakan SPSS 18.0, maka dapat diketahui bahwa data menyebar disekitar garis diagonal dan mengikuti arah garis diagonal, maka model regresi memenuhi asumsi normalitas.

Uji Heteroskedastisitas

Pengujian Heteroskedastisitas

Scatterplot

\begin{tabular}{|c|c|c|c|c|c|}
\hline \multicolumn{6}{|c|}{ Model Summary ${ }^{b}$} \\
\hline Model & & $\mathrm{R}$ & $\begin{array}{c}\mathrm{R} \\
\text { Squa } \\
\text { re }\end{array}$ & $\begin{array}{c}\text { Adjust } \\
\text { ed R } \\
\text { Squar } \\
\text { e }\end{array}$ & $\begin{array}{l}\text { Std. } \\
\text { Error } \\
\text { of the } \\
\text { Estim } \\
\text { ate }\end{array}$ \\
\hline $\begin{array}{r}\text { dimensi } \\
\text { on0 }\end{array}$ & 1 & $\begin{array}{r}.94 \\
8^{\mathrm{a}}\end{array}$ & $\begin{array}{r}.89 \\
9\end{array}$ & .784 & .565 \\
\hline
\end{tabular}

a. Predictors: (kepemimpinan, budaya organisasi, kompetensi, dan motivasi kerja

b. Dependent Variable: kinerja karyawan

\section{Gambar 4.2}

Sumber: Data Primer diolah (2020)

Dari grafik tersebut, dapat terlihat titik-titik yang menyebar secara acak, tidak membentuk suatu pola tertentu yang jelas, serta tersebar baik di atas maupun di bawah angka 0 (nol) pada sumbu Y, maka tidak terjadi heteroskedastisitas

\section{Uji Multikolinearitas}

tabel 4.10

Hasil uji Multikolinearitas

\begin{tabular}{|c|c|c|c|}
\hline $\begin{array}{r}\text { Vari } \\
\text { abel }\end{array}$ & \multicolumn{2}{|c|}{$\begin{array}{c}\text { Collinearity } \\
\text { Statistics }\end{array}$} & \multirow{2}{*}{ Kesimpulan } \\
\cline { 2 - 3 } Tolerance & VIF & \\
\hline $\begin{array}{c}\text { Kepemim } \\
\text { pinan }\end{array}$ & 0.370 & $\begin{array}{c}2.7 \\
04\end{array}$ & $\begin{array}{c}\text { Bebas } \\
\text { Multikolinearit } \\
\text { as }\end{array}$ \\
\hline $\begin{array}{c}\text { Budaya } \\
\text { Organisasi }\end{array}$ & 0.750 & 1.3 & $\begin{array}{c}\text { Bebas } \\
\text { Multikolinearit } \\
\text { as }\end{array}$ \\
\hline $\begin{array}{c}\text { Kompeten } \\
\text { si }\end{array}$ & 0.414 & 2.4 & $\begin{array}{c}\text { Bebas } \\
\text { Multikolinearit } \\
\text { as }\end{array}$ \\
\hline $\begin{array}{c}\text { Motivasi } \\
\text { Kerja }\end{array}$ & 0.441 & 2.2 & $\begin{array}{c}\text { Bebas } \\
\text { Multikolinearit } \\
\text { as }\end{array}$ \\
\hline \multicolumn{2}{|c|}{$\begin{array}{c}\text { Berdasarkan hasil } \\
\text { model rersebut maka } \\
\text { regresi }\end{array}$} \\
\hline
\end{tabular}

dalam model regresi tidak terjadi multikolinearitas atau korelasi yang sempurna antara variabel-variabel bebas, yaitu kepemimpinan, budaya organisasi, kompetensi, dan motivasi kerja karena nilai VIF lebih kecil dari 10 dan nilai tolerance lebih besar dari 0,1

\section{Koefisien Determinasi ( $\mathbf{R}_{\mathbf{2}}$ )}

Tabel 4.11

Hasil Model Summary

Sumber: Data Primer diolah (2020)

Nilai Adjusted $R$ Square menunjukkan besarnya kontribusi pengaruh variabel bebas terhadap variabel terikat dalam sebuah model. Hasil perhitungan yang disajikan pada tabel di atas menunjukkan nilai Adjusted $R$ Square $=0,883$. Hal ini berarti bahwa sebesar $88,3 \%$ konerka karyawan 
dipengaruhi oleh variabel bebas kepemimpinan, budaya organisasi, kompetensi, dan motivasi kerja sedangkan sisanya sebesar $11,7 \%$ dipengaruhi oleh variabel-variabel lain yang tidak diteliti.

\section{Uji Hipotesis}

Tabel 4.12

Pengujian Parsial

Coefficients $^{\mathrm{a}}$

\begin{tabular}{|c|c|c|c|c|c|}
\hline \multirow[t]{2}{*}{ Model } & \multicolumn{2}{|c|}{$\begin{array}{l}\text { Unstandardi } \\
\text { zed } \\
\text { Coefficients }\end{array}$} & \multirow{2}{*}{$\begin{array}{c}\text { Stand } \\
\text { ardiz } \\
\text { ed } \\
\text { Coeff } \\
\text { icient } \\
\text { s } \\
\text { Beta }\end{array}$} & \multirow[b]{2}{*}{$\mathrm{T}$} & \multirow[b]{2}{*}{ Sig } \\
\hline & B & $\begin{array}{l}\text { Std. } \\
\text { Error }\end{array}$ & & & \\
\hline 1 (Consta & 2.61 & 1.06 & & 2.4 & .02 \\
\hline & & 4 & & 58 & 1 \\
\hline Kepemi & -.032 & .087 & -.039 & - & .71 \\
\hline & & & & $\begin{array}{r}.37 \\
2\end{array}$ & 3 \\
\hline budaya & -.187 & .082 & -.166 & - & .03 \\
\hline organis & & & & 2.2 & 3 \\
\hline asi & & & & 63 & \\
\hline Kompet & .625 & .092 & .668 & 6.7 & .00 \\
\hline ensi & & & & 80 & 0 \\
\hline motivas & .374 & .088 & .406 & 4.2 & .00 \\
\hline i kerja & & & & 49 & 0 \\
\hline
\end{tabular}

a. Dependent Variable: kinerja karyawan

Sumber: Data Primer diolah (2020)

Hipotesis 1 :Kepemimpinan

Mempunyai Pengaruh Yang

Negatif Terhadap Kinerja Karyawan.

Hipotesis 2 :Budaya Organisasi Mempunyai Pengaruh Yang Negatif Terhadap Kinerja Karyawan.

Hipotesis 3 : Kompetensi Mempunyai Pengaruh Yang Positif Terhadap Kinerja Karyawan.

Hipotesis 4 : Motivasi Kerja Mempunyai Pengaruh Yang Positif Terhadap Kinerja Karyawan.

\section{PEMBAHASAN}

Kepemimpinan Mempunyai Pengaruh Yang Negatif Terhadap Kinerja Karyawan.

Dari hasil perhitungan diperoleh nilai $\mathrm{t}$ hitung untuk variabel kepemimpinan adalah sebesar -0,372 dan dengan menggunakan level significance (taraf signifikasi) sebesar 5\% diperoleh $\mathrm{t}$ table sebesar 2,059 yang berarti bahwa nilai $\mathrm{t}$ hitung lebih kecil dari $\mathrm{t}$ tabel yaitu $0,372<2,059$. Nilai signifikasi t lebih dari 5 $\%(0,713)$, menandakan bahwa kepemimpinan $\left(\mathrm{X}_{1}\right)$ mempunyai pengaruh yang negatif dan signifikan terhadap kinerja karyawan(Y). Dengan demikian dapat dinyatakan bahwa Ho diterima dan $\mathrm{H}_{1}$ ditolak,sehingga hipotesis yang menyatakan kepemimpinan mempunyai pengaruhyang positif terhadap kinerja karyawan ditolak.

Dari penjelasan tabel 4.10 pengujian parsial variabel kepemimpinan berpengaruh negatif terhadap kinerja karyawan dengan $\mathrm{T}$ hitung sebesar $-0,372$ dan nilai Sig 0,713 dan perhitungan tersebut lebih kecil dari $\mathrm{T}$ tabel $2,059$ ( $\operatorname{sig} 0,05)$. Hasil penelitian ini sejalan dengan penelitian yang dilakukan oleh Brahmasari dan Suprayetno (2008) yang mana variabel kepemimpinan sama- sama berpengaruh negatif dan ssignifikan terhadap kepuasan kinerja karyawan.

Budaya Organisasi Mempunyai Pengaruh Yang Negatif Terhadap Kinerja Karyawan.

Dari hasil perhitungan diperoleh nilai $t$ hitung untuk variabel budaya organisasi adalah sebesar -2,263 dan dengan menggunakan level significance (taraf signifikasi) sebesar 5\% diperoleh $\mathrm{t}$ tabel sebesar 2,059 yang berarti bahwa nilai $\mathrm{t}$ hitung lebih kecil dari $\mathrm{t}$ tabel yaitu $2,263<2,059$. Nilai signifikasi t kurang dari 5 $\%$ (0,033), menandakan bahwa budaya organisasi $\left(\mathrm{X}_{2}\right)$ mempunyai pengaruh yang negatif dan signifikan terhadap kinerja karyawan (Y). Dengan demikian dapat dinyatakan bahwa $\mathrm{Ho}$ diterima dan $\mathrm{H}_{2}$ ditolak,sehingga hipotesis yang menyatakan budaya organisasi mempunyai pengaruhyang positif terhadap kinerja karyawan ditolak.

Variabel budaya organisasi berpengaruh negatif terhadap kinerja

\section{Kompetensi Mempunyai Pengaruh Yang Positif Terhadap Kinerja Karyawan.}

Dari hasil perhitungan diperoleh nilai $t$ hitung untuk variabel kompetensi adalah sebesar 6.780 dan dengan menggunakan level significance (taraf signifikasi) sebesar 5\% diperoleh $\mathrm{t}$ tabel sebesar 2,059 yang berarti bahwa nilai $\mathrm{t}$ hitung lebih besar dari $\mathrm{t}$ tabel yaitu $6.780>2,059$. Nilai signifikasi t kurang dari 5 $\%$ (0,000), menandakan bahwa kompetensi $\left(\mathrm{X}_{3}\right)$ mempunyai pengaruh yang positif dan signifikan terhadap kinerja karyawan (Y). Dengan demikian dapat dinyatakan bahwa Ho ditolak dan $\mathrm{H}_{3}$ diterima, sehingga hipotesis yang menyatakan kompetensi mempunyai pengaruh yang positif terhadap kinerja 
karyawan diterima.

Variabel kompetensi berpengaruh positif terhadap kinerja karyawan dengan $\mathrm{T}$ hitung sebesar 6,780 dan nilai Sig 0,000 dan perhitungan tersebut lebih besar dari $\mathrm{T}$ tabel 2,059 ( sig 0,05). Hasil penelitian ini sejalan dengan penelitian yang dilakukan oleh Bahua, Angsari, Saleh dan Purnaba (2010) yang mana variabel kompetensi sama- sama berpengaruh secra positif terhadap kepuasan kinerja karyawan.

\section{Motivasi Kerja Mempunyai Pengaruh} Yang Positif Terhadap Kinerja Karyawan.

Dari hasil perhitungan diperoleh nilai $\mathrm{t}$ hitung untuk variabel motivasi kerja adalah sebesar 4.249 dan dengan menggunakan level significance (taraf signifikasi) sebesar 5\% diperoleh $\mathrm{t}$ tabel sebesar 2,059 yang berarti bahwa nilai $\mathrm{t}$ hitung lebih besar dari $\mathrm{t}$ tabel yaitu $4.249>2,059$. Nilai signifikasi t kurang dari 5 $\%(0,000)$, menandakan bahwa motivasi kerja $\left(\mathrm{X}_{4}\right)$ mempunyai pengaruh yang positif dan signifikan terhadap kinerja karyawan (Y). Dengan demikian dapat dinyatakan bahwa Ho ditolak dan $\mathrm{H}_{4}$ diterima, sehingga hipotesis yang menyatakan kompetensi mempunyai pengaruh yang positif terhadap kinerja karyawan diterima.

Variabel motivasi kerja berpengaruh positif terhadap kinerja karyawan dengan $\mathrm{T}$ hitung sebesar 4,249 dan nilai Sig 0,000 dan perhitungan tersebut lebih besar dari $\mathrm{T}$ tabel 2,059 ( sig 0,05). Hasil penelitian ini sejalan dengan penelitian yang dilakukan oleh Gani (2008) yang mana variabel motivasi kerja sama- sama berpengaruh secra positif terhadap kepuasan kinerja karyawan.

\section{Simpulan}

\section{SIMPULAN DAN SARAN}

Berdasarkan hasil penelitian, hasil analisis dan pembahasan yang telahdikemukakan oleh penulis terhadap keputusan pada Koperasi Simpan Pinjam Sumber Jaya Lamongan pada bab- babsebelumnya, maka dapat ditarik kesimpulan dari keseluruhan hasil analisissebagai berikut :

1. Variabel kompetensi, dan motivasi kerja berpengaruh signifikan secara parsial terhadap kinerja karyawan pada Koperasi Simpan Pinjam Sumber Jaya Lamongan.

2. Variabel kepemimpinan, budaya organisasitidak berpengaruh signifikan secara parsial terhadap kinerja karyawan pada Koperasi Simpan Pinjam Sumber Jaya Lamongan.

3. Variabel faktor kepemimpinan, budaya organisasi, kompetensi, dan motivasi kerja berpengaruh signifikan secara simultan terhadap kinerja karyawan pada Koperasi Simpan Pinjam Sumber Jaya Lamongan.

4. Variabel Kompetensi, merupakan variabel yang mempunyai pengaruh paling dominan terhadap kinerja karyawan karena variabel tersebut mempunyai nilai t-hitung yang lebih besar jika dibandingkan dengan variabel lain, yaitu sebesar 6.780 dan angka Sig. yang paling kecil yaitu sebesar 0,000.

5. Besarmya kontribusi pengaruh variabel kepemimpinan, budaya organisasi, kompetensi, dan motivasi kerja terhadap kinerja karyawan pada Koperasi Simpan Pinjam Sumber Jaya Lamongan.adalah sebesar $78,4 \%$ dan sisanya dipengaruhi oleh variabel lain yang tidak teliti.

\section{Saran}

Saran-saran sebagai masukan bagi pihak perusahaan yaitu sebagai berikut :

1. Pimpinan harus memperhatikan faktorfaktor yang dapat meningkatkan kinerja karyawan seperti kepemimpinan, budaya organisasi, kompetensi dan motivasi kerja sebagai dasar dalam pengembilan keputusan untuk meningkatkan kinerja karyawan merasakan keseimbangan antara hak dan kewajibanya serta mampu dengan giat bekerja sesuai dengan perintah atasan.

2. Mengingat masa kerja yang relatif lama dari para karyawan sebaiknya pimpinan berinisiatif untuk melakukan aktivitasaktivitas baik di dalam maupun di luar pekerjaan yang dapat memberikan motivasi kerja kepada para karyawan agar tidak mengalami kejenuhan yang berakibat terjadinya kemangkiran karyawan yang tentu saja merugikan dan menurunya kinerja karyawan.

\section{DAFTAR PUSTAKA}

Abdullah Ma'ruf (2014), Manajemen dan Evaluasi Kinerja Karyawan, Aswaja Pressindo, Sleman, Yogyakarta.

Brahmasari Ayu Ida dan Suprayetno Agus, 2008, Pengaruh motivasi kerja, kepemimpinan dan budaya organisasi terhadap kepuasan kerja karyawan serta dampaknya pada kinerja perusahaan (studi kasus pada PT. Pei Hai International Wiratama Indonesia), Universitas 17 Agustus Surabaya. 
Gani Achmad, 2008, Analisis faktor- faktor yang mempengaruhi kinerja pegawai kantor pelayanan pajak bumi dan bangunan kota makasar,Universitas Muslim Indonesia Makasar.

Harison dalam Sedarmayanti(2016), Manajemen Sumber Daya Manusia, Cetakan kelima, Edisi Revisii, PT Refika Aditama, Bandung.

Sedarmayanti (2016), Manajemen Sumber Daya Manusia, Cetakan kelima, Edisi Revisii, PT Refika Aditama, Bandung.

Spencer dalam Abdullah Ma'ruf, (2014), Manajemen dan Evaluasi Kinerja Karyawan, Aswaja Pressindo, Sleman, Yogyakarta.

Sugiyono (2010), Metode penelitian Bisnis, Cetakan Lima Belas, Alfabeta, Bandung.

Wibowo, dalam Abdullah Ma'ruf (2014), Manajemen dan Evaluasi Kinerja Karyawan, Aswaja Pressindo, Sleman, Yogyakarta. 